\title{
FAMILY AND SOCIOCULTURAL CHARACTERISTICS OF THE OWNERS OF SELECTED FARMS IN VOJVODINA
}

\author{
Marina Novakov ${ }^{1}$, Dejan Janković ${ }^{2}$, Marica Petrović ${ }^{3}$ \\ *Corresponding author E-mail: jankovic@polj.uns.ac.rs
}

\begin{abstract}
A R T I C LE IN F O
A B S T R A C T

Original Article

Received: 15 August 2018

Accepted: 01 September 2018

doi:10.5937/ekoPolj1803015N

UDC 316.613:631.1(497.113)

Keywords:

rural family, economic position, reproduction, division of labour, characteristics of marital life

JEL: R20, Q16, Z13

The paper analyzes the characteristics of family life of households on selected farms in the area of AP Vojvodina based on the results of the evaluation of the extension service activities. The evaluation was done on a representative sample. The aim of the paper is to gain insight into socio-cultural features, the characteristics of the households, the marital contingent, and the distribution of authority, and (gender) division of labour in the holding. It is concluded that some of the characteristics of a rural household, when family life is concerned, have changed, that attitudes about the gender division of work have been evolved, while the practices, however, remained the same, which testifies to their deep rootedness and the matrix of behaviour that is changing rather slowly.
\end{abstract}

(C) 2018 EA. All rights reserved.

\section{Introduction}

During the past century, the traditional family has undergone major changes. The specificities of the rural environment and the family require special attention when planning the development strategy of the local rural communities, and the population and social policies that would respect the particularity of certain categories of population.

The general state of a global society has led to changes in family structure and family relationships. Global social changes, such as industrialization and modernization, have affected both the rural family and the rural per se, since they are not an isolated segment of society, nor can they be observed in such way. The rural family (and women as its backbone) for a long time were neglected in Serbian sociological research. The main theoretical standpoints in that field of research that formed the theoretical basis for the

1 Dr Marina Novakov, researcher, University of Novi Sad, Faculty of Agriculture, Department of Agricultural Economics and Rural Sociology, Trg Dositeja Obradovića 8. Novi Sad. Phone: +381214853328; e-mail: marinan@polj.uns.ac.rs, ORCID ID: 0000-0001-7448-395.

2 Dr Dejan Janković, Assistant Professor. University of Novi Sad, Faculty of Agriculture, Department of Agricultural Economics and Rural Sociology, Trg Dositeja Obradovića 8. Novi Sad. Phone: +381214853381; e-mail: jankovic@polj.uns.ac.rs , ORCID ID: 0000-0002-2609-125X.

3 MSc. Marica Petrović, Teaching Assistant. University of Novi Sad, Faculty of Agriculture, Department of Agricultural Economics and Rural Sociology, Trg Dositeja Obradovića 8. Novi Sad. Phone: +381214853270; e-mail: maricam@polj.uns.ac.rs, ORCID ID: 0000-0003-2539-7465.

http://ea.bg.ac.rs 
analysis in this paper include, first of all, studies conducted in Serbia country, which are: 1) views on the transformation of the enlarged patriarchal family and the confrontation of patriarchal and industrial principles at the time of the transformation of society, attitudes about continuity and changes in the rural family (Erlih, 1971); 2. Emphasis on the importance of the rural household and farm as the main production unit, and the former interrelation between family and production relations in the farmers' family (First, 1973, 1973a, 1981); 3. Views on the "sacrificial micro matriarchate" and the continuity of sacrifice as a long-term pattern of life in these areas, which was restored during socialism and transition (Blagojević, 1997); 4. Attitudes in regards to the characteristics of the cultural pattern of maternity of Serbs (Tripković, 1997); 5. An understanding of the re-traditionalization of family relations and the transformation of family and households due to the social crisis (Milić, 1986, 1989, 2004; Tomanović, 2006); and 6. Studies dealing with Serbian rural areas, culture and landmarks of the households and farms (Mitrović, 1999; Tripković, 1987; Šljukić, Janković, 2015; Bogdanov, Babović, 2014).

The family and main socio-cultural characteristics of households on farms are of great importance when it comes to analyzing the specificity of the conditions in which the agricultural extension process takes place. For this reason (among other data), these information were included in the project Evaluation of the work of the agricultural extension service of the AP Vojvodina, whose part of the results are presented in this paper. The survey covered 81 inhabited places in all seven districts in the area of AP Vojvodina and the sample is representative in every sense. For a long time, in Serbian sociological research there was a vacuum in investigation of rural families. Such a situation has been somewhat changed over the past decades, and this research is one of the ones that, among other, gives insights into the microcosm of rural life. This paper analyzes socio-economic characteristics of households, marital contingents, distribution of authority, and gender division of labour in the household.

\section{Material and method}

The analysis in this paper is based primarily on the results of the aforementioned project Evaluation of the Work of the Agricultural Extension Service of the Autonomous Province of Vojvodina with the selected agricultural farms, which was realized in 2012/2013. ${ }^{4}$ The evaluation was conducted during 2012/2013. on the basic assembly of 4,112 selected farms and 92 advisors PSS APV. The sample was proportional and stratified. Territorial coverage was of all 13 agricultural extension services in AP Vojvodina, all engaged advisors, all specialities of their work, all types and sizes of selected farms.

4 The project leader was prof. dr Živojin Petrović, and coordinator of the project prof. dr Dejan Jankovic. The project was realized with the support of the Provincial Secretary of Agriculture, Water Management and Forestry of Vojvodina and the Department of Agricultural Economics and Rural Sociology, the Centre for Rural Development, Education and Training of Agricultural Advisors. 
As the basis for the selection of the sample for the evaluation, only those selected farms for which there necessary basic data existed were taken into account. Thus, the data gathering was reduced to 2987 farms, and the sample was $10 \%$, or 294 households. In the final analysis, the collection of necessary data has been done on a sample of a total of 281 selected farms, which means that $95.2 \%$ of the predicted sample was realized, which results can be qualified as representative. Each farm was visited by the interviewer and an interview with the householder was conducted. In the data collection participated 17 interviewers who had previously undergone basic training for going to the field. The questionnaire was divided into six segments and contained a total of 154 questions. One segment concerned exactly the family and household whose results and present the subject of the analysis of this paper. The results presented in this paper are also based on the analysis of data from the Census of Population, Households and Flats of R. of Serbia that was conducted in 2002 and 2011, as well as other publications of the Republic Institute for Statistics of Serbia.

\section{Results and discussion}

\section{Socio-economic features of the households}

The gender structure of the sample was dominated by men $(95 \%)$, which is nineteen times more than female respondents (5\%). The overwhelming age of respondents is between 40 and 59 years old (60.9\%). Respondents aged between 30 and 39 are $16 \%$, the age group of $60+$ is represented by $18.8 \%$, and the smallest of young people aged between 18 and 29 years $(4.3 \%)$.

When considering the educational structure of the rural population according to the latest Census on the whole country, it is noted that today the secondary school is the most frequent degree of education of the rural population $(42.37 \%)$. Second place is represented by primary education $(27.68 \%)$, and only $(6.1 \%)$ have higher or higher education. The highest number of households from the representative sample of selected agricultural farms in Vojvodina has completed secondary school (62.3\%), which corresponds with the data of the Census on the most frequently achieved education on the territory of both Serbia and the region of Vojvodina. However, the educational structure of the household is somewhat more favorable than the overall rural population. Thus, $19.9 \%$ of households have an incomplete elementary or elementary school, while in Vojvodina the proportion of people in rural settlements with lower secondary education is $46.78 \%$. Higher school completed have $7.8 \%$ and college every tenth householder. There is a high statistically significant and medium strong relationship between education and age of the farmer $(\mathrm{c} 2=56,229 ; \mathrm{p}=0,000 ; \mathrm{C}$ $=0,408)$, but not between this variable and the gender of the respondents $(\mathrm{c} 2=1,547 ; \mathrm{p}$ $=0,818$ ). It turned out that the level of education lower from the secondary is the most represented among the oldest farmers (65+ years). Secondary school is also the most frequently achieved educational level of the husband/wife of the respondents $(54.1 \%)$. 
Table 1. Occupation of household keeper and spouse (\%)

\begin{tabular}{|c|c|c|}
\hline Occupation & Household keeper & Spouse \\
\hline farmers & 77,9 & 45,2 \\
\hline workers & 7,1 & 10,0 \\
\hline merchants & 0,4 & 0,4 \\
\hline craftsmen and service activities & 0,7 & 2,5 \\
\hline civil servants & 3,9 & 6,4 \\
\hline experts-professionals & 1,4 & 6,0 \\
\hline managers, directors & 3,6 & 1,8 \\
\hline $\begin{array}{c}\text { persons with personal income (pensioners, } \\
\text { persons under guardianship...) }\end{array}$ & 4,6 & 6,8 \\
\hline unemployed, housewife & - & 8,2 \\
\hline no spouse & - & 7,5 \\
\hline no answer & 0,4 & 5,3 \\
\hline TOTAL & 100,0 & 100,0 \\
\hline
\end{tabular}

Source: Authors' calculations

Among the interviewed householders in the structure of occupations, the greatest percentages are farmers $(77.9 \%)$. The category of occupation of their spouse also dominates this category (Table 1). Interestingly, spouses are almost six times more likely to be represented among professionals than their own householders.

Former large families, family co-operatives, with many children and relatives living together, belong to past times. They were replaced by small family. The average size of the household in Serbia is 2.88 members and in the Vojvodina region 2.76 members (Census, 2013: 29). The situation is somewhat different at the sample level where the average number of household members is 4.26. Among the respondents, the largest share is of four-member households (34.5\%). The next are three member families. Six or more members have only $18.6 \%$ of households, while the smallest share is of single families (2.1\%) (Figure 1).

Figure 1. Number of household members (\%)

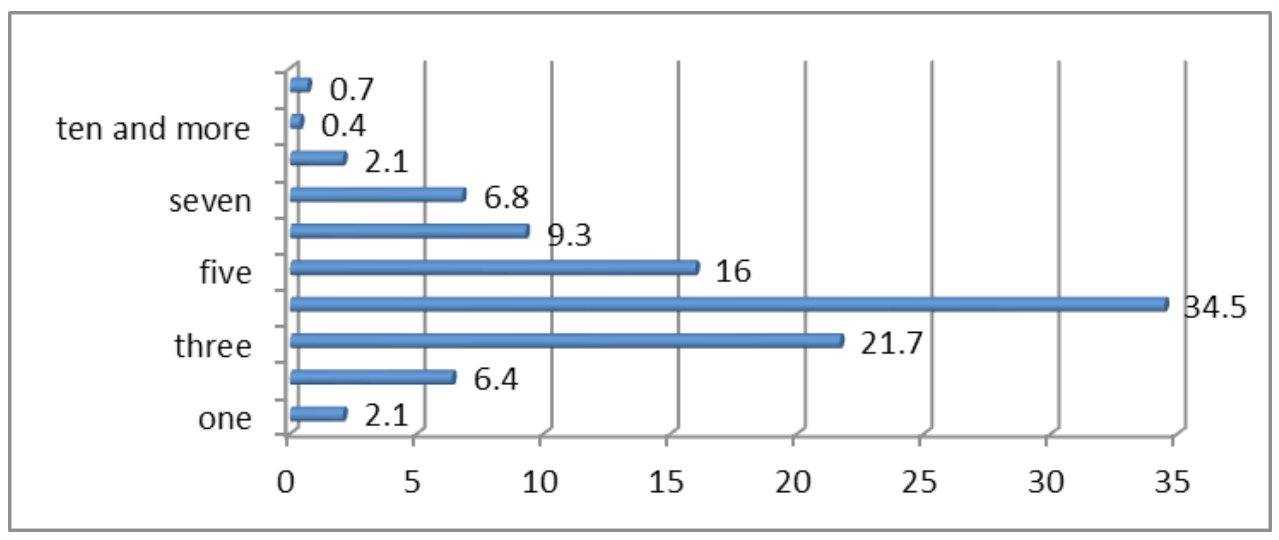

Source: Authors' calculations 
Regarding the economic situation of the household, approximately every tenth householder (9.6\%) said that they have difficulty allocating funds for paying monthly bills, and $4.3 \%$ have a problem and allocate funds for medicines. About one in ten respondents $(10.7 \%)$ have difficulty allocating funds for car maintenance and $27 \%$ have this problem with going to vacation. It is interesting to note that as many as 96.4 households own a car.

The economic status of their households $84.3 \%$ of the surveyed households assessed as good, while almost every ninth assessed that their material position was poor $(11.7 \%) .1 .4 \%$ of households assessed a very good financial situation of the household and, on the other hand, slightly more responded that the material situation was very poor (2.1\%). Man-Whitney test showed that there is a statistically significant relationship between the estimation of the economic position and the type of household, but Cohen's criterion for this effect is small $(\mathrm{U}=8765, \mathrm{z}=-2,436, \mathrm{p}=0,015, \mathrm{r}=0,145)$. Thus, the assessment of the economic situation of a household according to the type of household (purely agricultural or mixed) shows that households with mixed incomes assessed their economic position as three times more often as very good. Respondents who have pure agricultural holdings (incomes) in $69.7 \%$ of cases estimated that their material situation is very poor. Considerably fewer respondents (30.3\%) who have mixed households (incomes) have assessed the material situation as very poor (Table 2). On the other hand, Spearman's correlation coefficient indicates that there is no statistically significant relationship between the own estimation of the economic position and the number of household members $\left(r_{S}=-0,053, p=0,0380\right)$. Also, the Kruskal-Wallis test showed that there is no statistically significant relationship between the own assessment of the economic position and education $(\mathrm{KW}=2.833, \mathrm{p}=0.586)$, and the owner's occupation $(\mathrm{KW}=1.208, \mathrm{p}=0.991)=9.841, \mathrm{p}=0.08)$.

Table 2. Respondents' estimation of the economic situation by type of household

\begin{tabular}{|c|c|c|c|}
\hline \multirow{2}{*}{$\begin{array}{c}\text { How do you estimate the economic } \\
\text { position of your household? }\end{array}$} & $\begin{array}{c}|c| \\
\text { Type of household } \\
\text { household (farm) }\end{array}$ & $\begin{array}{c}\text { Mixed } \\
\text { household }\end{array}$ & \\
\cline { 2 - 3 } & $25,0 \%$ & $75,0 \%$ & $100,0 \%$ \\
\hline Very good & $46,8 \%$ & $53,2 \%$ & $100,0 \%$ \\
\hline Good & $69,7 \%$ & $30,3 \%$ & $100,0 \%$ \\
\hline Bad & $50,0 \%$ & $50,0 \%$ & $100,0 \%$ \\
\hline Very bad & $49,3 \%$ & $50,7 \%$ & $100,0 \%$ \\
\hline TOTAL & & \\
\hline
\end{tabular}

Source: Authors' calculations

The economic situation of the household today, compared to five years ago, is estimated as partially improved by $34.2 \%$ of respondents. Every fourth respondent said that the economic situation in the observed period remained the same $(25.7 \%)$. There are also farmers $(23.2 \%)$ who estimate that the economic situation worsened. Among those whose perception is that there has been a significant change in the economic situation of the household in relation to the period of five years ago, there are more of those who give a negative than a positive rating. Thus, $10.7 \%$ of respondents answered that the situation worsened considerably, compared to $6.1 \%$ who said they had improved significantly. 
When cross tabulating the data on the assessment that the respondents gave about the economic situation of their household today and an estimate of it five years ago (Table 3 ), it follows that the largest number of respondents who assessed the economic situation as very good, also said that it has improved it in relation to the five years ago $(75 \%)$. On the other hand, the largest number of respondents who assessed the economic situation as very bad, at the same time gave the answer that the situation worsened in relation to the period of five years ago $(50 \%)$.

Table 3. Estimation of the economic situation today and five years ago

\begin{tabular}{|c|c|c|c|c|c|c|}
\hline \multirow{2}{*}{$\begin{array}{c}\text { Estimation } \\
\text { of economic } \\
\text { position of the } \\
\text { household }\end{array}$} & \multicolumn{5}{|c|}{$\begin{array}{c}\text { Economic position of your household today in comparison to five } \\
\text { years ago? }\end{array}$} & \multirow{2}{*}{ TOTAL } \\
\hline & $\begin{array}{l}\text { significantly } \\
\text { improved }\end{array}$ & $\begin{array}{l}\text { partially } \\
\text { improved }\end{array}$ & $\begin{array}{l}\text { remained } \\
\text { the same }\end{array}$ & $\begin{array}{l}\text { partially } \\
\text { worsened }\end{array}$ & $\begin{array}{c}\text { considerably } \\
\text { worsened }\end{array}$ & \\
\hline Very good & $75,0 \%$ & $25,0 \%$ & $0,0 \%$ & $0,0 \%$ & $0,0 \%$ & $100,0 \%$ \\
\hline Good & $5,5 \%$ & $37,6 \%$ & $27,4 \%$ & $23,6 \%$ & $5,9 \%$ & $100,0 \%$ \\
\hline $\mathrm{Bad}$ & $3,0 \%$ & $18,2 \%$ & $18,2 \%$ & $21,2 \%$ & $39,4 \%$ & $100,0 \%$ \\
\hline Very bad & $0,0 \%$ & $0,0 \%$ & $16,7 \%$ & $33,3 \%$ & $50,0 \%$ & $100,0 \%$ \\
\hline TOTAL & $6,1 \%$ & $34,3 \%$ & $25,7 \%$ & $23,2 \%$ & $10,7 \%$ & $100,0 \%$ \\
\hline
\end{tabular}

Source: Authors' calculations

\section{Characteristics of marital and family life}

In a Serbian traditional society marriage was considered as the only legitimate framework for reproduction. The appearance of out-of-wedlock birth was viewed negatively, and the social community was severely condemning them. In addition, it was taken care that young people did not get too old and to marry "on time". This age for women did not exceeded 20 and for men 25 years. The main reason for making early marriages in rural areas was shortages of labor force. By getting married another needy worker was provided in the house, and the reasons for the early marriage were that one sometimes rushed into the marriage to grab a rich girl, or to create a friendship between two families that have "fine reputation" (Đorđević, 1930).

The official regulations also failed to change early marriage. The first regulation in Serbia determining age at marriage dates back to 1837 when it was established that the males could not get married before the age of 17 and females before the age of 14. However, they were not strictly respected because they were inconsistent with the national understanding of the age for marriage (Đorđević, 1930, Novakov, 2011). In the middle of the last century, the Marriage Act of 1946 did not allow the marriage of spouses under the age of 18, except with the special approval of the court. The average age of entering the first marriage in Serbia in 1952 was 23.8 years for a groom and 21.6 for bride (Burić, 1963: 79.84). That average in 2015, at the conclusion of the first marriage, rose to 31 years for men, and 28 years for women (RZS Press, 2016).

Serbia still has a high marriage rates, and marriage as an institution is still highly valued. More than half, or $57 \%$ of men and $53 \%$ of women over 15 years of age, live 
in a marriage/community (Women and men in Republic of Serbia, 2014) in Serbia. However, in Serbia marriage is concluded, as we have seen, in the later life span, the birth decision is postponed, and the former feature of rural areas - high fertility - is replaced by the fact that according to the last Census, there is majority of families with only one child $51.79 \%$ ) followed by families with two children (40.05\%) (Census, book 17, 2014).

When considering the structure of households on the realized sample of households on selected farms, it follows that the most represented families of nuclear type are parents and children (49.8\%), followed by extended families $(36.7 \%)$. The households of a married couple without children make only $4.3 \%$ of the sample, single-parent families are $2.8 \%$ and single ones only $2.1 \%$ (Figure 2 ).

Figure 2. Structure of the family of respondents

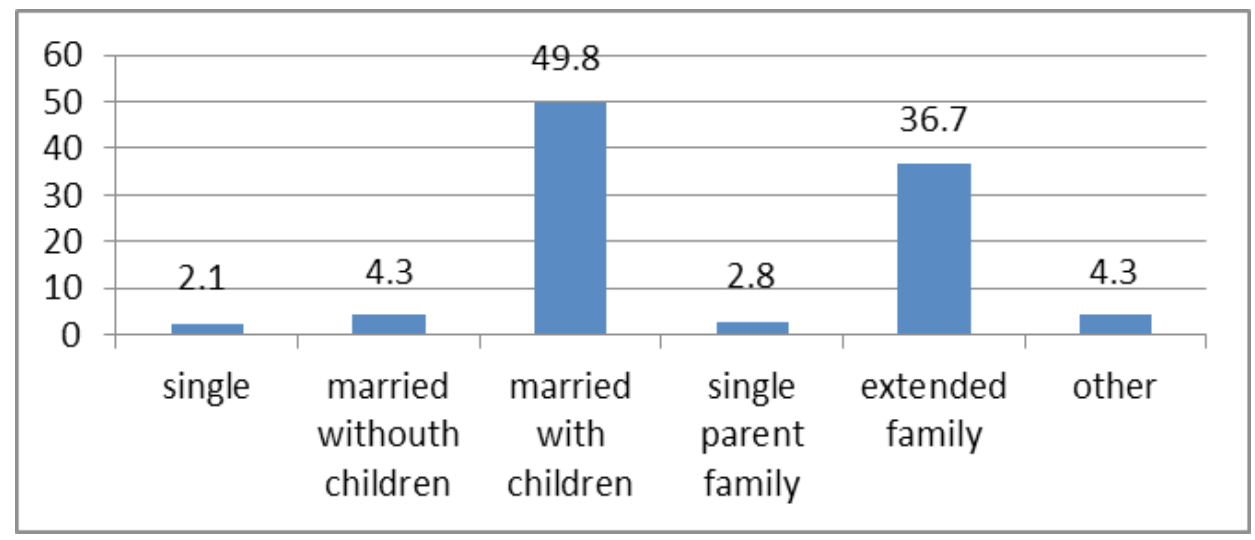

Source: Authors' calculations

The surveyed householders also have high level of marriage: $88.3 \%$ are married, $7.8 \%$ are single, $2.5 \%$ are widowed, while $1.4 \%$ in the extra-marital community. In addition, the most numerous are householders who are married for 15 years or more $(70.8 \%)$, $14.9 \%$ are married between 6 and 14 years and $4.2 \%$ to 5 years. The age of marriage was shifted to later years of the marital contingent, but still somewhat lower than on the whole country: by the age of $20,6.8 \%$ of respondents entered the marriage, and $71.2 \%$ of them were between the age of 21 and 29 years. After thirty, only about one fifth respondent got married (22.9\%). Householders were mostly married with bride/ groom from the same village where they live (43.4\%), that testifies to high geographical homogeneity, $32.7 \%$ have a spouse who originates from another village, and only $14.2 \%$ of spouses lead origin from a city. Such a small number of settlers from the city supports the long ago stated claims that, first of all, village girls try to migrate through marital mobility or, in the case of students, stay in town, and city girls rarely (and reluctantly) decide to move to the village .

We sought to investigate the marital/family authority through the question of deciding the respondents and family members about the purchase of land, agricultural machinery, http://ea.bg.ac.rs 
investments in auxiliary facilities or house, taking the land for rent, as well as the features of buying everyday goods and education for children. It turned out that most decisions of the householders are usually made independently, except when it comes to equipping a home, which is decided with her husband. Women do not usually decide on agricultural production, although they are included in it. In addition, the only item that is most commonly decided by wife is the purchase of everyday foods since the house is a "woman" sphere and that they know best what is missing in the house at the daily level (Table 4).

Table 4. The structure of the decision-making on households

\begin{tabular}{|c|c|c|c|c|c|}
\hline $\begin{array}{c}\text { Who mostly decides in } \\
\text { household regarding: }\end{array}$ & Householder & Spouse & $\begin{array}{c}\text { All grown- } \\
\text { up family } \\
\text { members }\end{array}$ & $\begin{array}{c}\text { Householder } \\
\text { and spouse } \\
\text { together }\end{array}$ & Other \\
\hline Land purchase & 45,9 & 1,1 & 17,4 & 23,5 & 12,1 \\
\hline Leasing of the land & 47,3 & 0,4 & 16,0 & 21,4 & 14,9 \\
\hline $\begin{array}{c}\text { Investments in the construction } \\
\text { and expansion of auxiliary } \\
\text { facilities }\end{array}$ & 44,8 & 0,7 & 18,5 & 24,2 & 11,8 \\
\hline $\begin{array}{c}\text { Investments in the house } \\
\text { construction and expansion }\end{array}$ & 37,7 & 1,4 & 19,2 & 30,2 & 11,5 \\
\hline Equipping the house & 28,8 & 10,3 & 19,9 & 32,0 & 9,0 \\
\hline $\begin{array}{c}\text { Purchase of agricultural } \\
\text { machinery }\end{array}$ & 45,6 & 1,8 & 17,8 & 23,5 & 11,3 \\
\hline Purchase of everyday foods & 15,7 & 33,8 & 16,0 & 25,3 & 9,2 \\
\hline Children education & 12,1 & 11,0 & 11,4 & 51,2 & 14,3 \\
\hline
\end{tabular}

Source: Authors' calculations

Half the last century, the family survived the big changes. While high fertility represented risk insurance in traditional societies, today the birth of a small number of children is also a way to avoid risk (Rašević, 1999: 31). Sometimes children were a significant work resource, especially in rural areas. Moreover, they were also a kind of insurance for old age: someone who will care for the elderly parents and someone who will continue the family tradition (celebrating family "slava"). So the reasons for the large number of children in rural families were economic and religious. In addition, male children were particularly preferred. The former need for a large number of children has been replaced by a high cost of parenting. In addition to giving sense in life for humans, parenting also requires considerable economic, psychological, and emotional resources. Thus, in modern conditions of life, norms have been adopted on a small number of children in the family - two children, possibly of a different sex, have become the desired reproductive norm in many countries. 
Table 5. Families according to the number of children in the territory of Serbia data by region

\begin{tabular}{|c|c|c|c|c|c|c|}
\hline \multirow{2}{*}{ Region } & \multicolumn{6}{|c|}{ Number of children in family } \\
\cline { 2 - 7 } & Total & $\mathbf{1}$ & $\mathbf{2}$ & $\mathbf{3}$ & $\mathbf{4}$ & $\begin{array}{c}\mathbf{5} \text { and } \\
\text { more }\end{array}$ \\
\hline Belgrade region & 24,06 & 25,13 & 23,34 & 21,36 & 18,19 & 17,95 \\
\hline Vojvodina region & 27,09 & 27,57 & 26,60 & 26,08 & 26,69 & 32,81 \\
\hline Šumadija and West Serbia & 27,98 & 26,52 & 28,64 & 33,89 & 36,25 & 30,00 \\
\hline South and East Serbia & 20,87 & 20,78 & 21,42 & 18,67 & 18,86 & 19,24 \\
\hline Republic of Serbia & 100 & 51,79 & 40,05 & 6,73 & 1,07 & 0,36 \\
\hline
\end{tabular}

Source: Population census (2014): 28, 34

In Serbia population growth (balance) is negative for many years/decades. At the beginning of this century, it ranged from -3.3 promille in 2002, up to -4.9 in 2014 . (Statistical Yearbook 2015: 35). Thus, according to the latest Census data, in Serbia the most prevalent families with one child are now (Table 5).

At the level of realized household sample, this situation is somewhat different in that the respondents most often had two children (62.2\%). Three and more children had 13.2\% of households (Table 6). Interestingly, householders often find that the preferred/ideal number of children in the family is three (45.2\%), 32\% consider them desirable, and every tenth (10.3\%) preferred four children. Five and more children are desirable for $7.8 \%$ of households, while $2.8 \%$ did not respond. Only $1.8 \%$ of respondents responded it was ideal for families to have one child. In addition, they do not tie the perspective of their children to agriculture. Only slightly more than half $(52.3 \%)$ of householders said they would like their children to be engaged in agriculture. As a reason, they most often responded that someone should inherit a job and that this is a family tradition. On the other hand, among the respondents who do not have a desire for their offspring to deal with agriculture, the majority of householders who explained their position by saying that there is no prospect in agriculture and that it is a difficult and unprofitable and unsafe job. It is important to note at this point that based on the value of c2 test $(\mathrm{c} 2=29.448 ; \mathrm{p}=0.000)$ and the calculated value of the coefficient of contingency $(\mathrm{C}$ $=0.308$ ), it can be concluded that there is a high statistically significant and moderate dependence of the expressed desire for children to be engaged in agriculture and the intentions of householders to improve agricultural production on their farm in the near future. So there are more householders who intend to invest in agriculture among those who at the same time want their children to deal with agriculture.

Table 6. The number of children in the family (\%)

\begin{tabular}{|c|c|c|c|c|c|c|}
\hline $\begin{array}{c}\text { Number of } \\
\text { children }\end{array}$ & One & Two & Three & $\begin{array}{c}\text { Four and } \\
\text { more }\end{array}$ & No children & Total \\
\hline Frequency & 41 & 176 & 30 & 7 & 27 & 281 \\
\hline Percent & 14,6 & 62,2 & 10,7 & 2,5 & 9,6 & 100 \\
\hline
\end{tabular}

Source: Authors' calculations 
There is no statistically significant relationship between the desire for children to deal with agriculture and the type of farm they live on $(c 2=2.896 ; p=0.235)$. However, ManWhitney's test showed that there was a statistically significant relationship between the variables of the assessment of the economic position, on the one hand, and the desire for children to deal with agriculture $(U=6797 ; z=-3,207 ; p=0,001 ; r=0,191)$ on the other side. Thus, it is much more common for householders who estimate the economic position of the household as very good and good and desirable future of their children for agriculture. However, according to Cohen's criterion, the impact of the assessment of the economic position and prospects for children in agriculture is small.

\section{Gender division of labor in the household}

For a long time the rural family functioned as a working community in which they knew exactly what were male and female tasks and duties. It was hard to see a man who wants to clean the yard, to milk a cow or do home duties, while on the other hand, women were less ashamed to do "male" jobs (Vukosaljević, 1983). Women generally worked less hard work, and jobs that did not require professional training. So they were mostly related to the house: they prepared food, guarded children, weaved, and so on. In addition to the gender division of labor, in Serbian traditional society there was a division of labor according to age.

The modernization of agriculture has largely altered the traditional gender division of labor. Today, most male jobs can also be female ones. The greater participation of women's workforce in agriculture was also due to the migration of male labor force towards the city. The employment of men outside the holding required an increased involvement of the woman in the household (Stojanov, 1989), which additionally burdened the rural woman and increased her importance on the farm, since she took on many traditional men's jobs. In addition, it should be kept in mind that this additional work in agriculture was more a consequence of necessity than its choice, and also the employment of women themselves is considered one of the main factors of changes that have taken place in the family and family relations (Novakov, 2011a).

At the level of our sample, the highest levels of engagement in agriculture have household keepers (59.4\%), while $36.7 \%$ of respondents answered that all members of the family are engaged. On the other hand, when it comes to doing housework - the wives are in charge of them. The research on the socio-economic status of women with the status of "assistant member in the household" that was conducted in 2008 (Babović, Vukovic, 2009) showed that men have the dominant power in deciding on agricultural production, while women are left with home and home-related decisions tasks. So, at the level of our sample, females are in $69.8 \%$ of cases in charge of cooking, and only $5.1 \%$ answered that men and women are involved in the preparation of food. Women are in $74 \%$ of the families in charge and for ironing (only 3.2\% of respondents participate together with their wives), and for cleansing 70.8\% (together with husband 5.7\%). The greater involvement of the husband is noticeable only in the care of children, where mother is also predominant (52.7\%), and more often fathers are engaged with their 
mother $(24.2 \%)$. Another area of day-to-day engagement in which common activity is noticeable is the procurement of foodstuffs: women themselves make purchases in $60.1 \%$ of families and in $16 \%$ with their husbands. Most householders $(77.8 \%)$ stated that they never perform any housework or some of them (cooking, washing, ironing ...), while only $17.4 \%$ answered that there is no such job that they never engage in. These jobs are in $59.8 \%$ of cases performed by wives. Therefore, there is a division of labor in the household today. Thus, $75.1 \%$ of householders stated that there are jobs in which wives do not participate on their farms. These are: all the field jobs in agriculture $(26 \%)$, jobs with and regarding mechanization (13.2\%), heavy physical work and field work $(8.2 \%)$, land treatment $(6.4 \%)$, crop production jobs $(4.6 \%)$, plowing $(2.1 \%)$ and others. These are also the jobs that householders consider typical for male jobs in agriculture. On the other hand $(18.5 \%)$ of the respondents stated that there are typical female jobs in agriculture, such as vegetable growing, gardening and greenhouse work, milking, floristry, and cattle jobs.

Constant participation in agricultural works is somewhat more prevalent among older women in the household, than in younger ones (Table 7). So, approximately one in four old women $(27.4 \%$ ) always participate in agricultural work, and $19.6 \%$ younger women. In doing so, elderly women are most often involved in cattle jobs, then, as the householders answered "in everything that is needed", in the maize storage and vegetable production. Younger women are also most often involved in cattle jobs, vegetable farming, all work and manual corn storage activities.

Table 7. Participation of women in agricultural work

\begin{tabular}{|c|c|c|}
\hline Do they participate in agricultural work & Older women & Younger women \\
\hline always & 27,4 & 19,6 \\
\hline sometimes & 16,4 & 13,9 \\
\hline only during the season & 12,5 & 9,3 \\
\hline rarely & 7,5 & 5,3 \\
\hline never & 21,4 & 20,3 \\
\hline there are no such members in household & 10,0 & 14,2 \\
\hline no answer & 5,0 & 17,4 \\
\hline Total & 100,0 & 100,0 \\
\hline
\end{tabular}

Source: Authors' calculations

Only each twelfth respondent $(8.2 \%)$ answered that there are jobs in their household that are shameful for a man to do, and that these are primarily all housework or some of them. So it's about the so-called "female" jobs. Based on these results, it can be said that the rural population's attitudes evolved, but the practices remained largely the same.

In Serbian traditional society, joint and collective works were one of the important ways of doing agricultural works when they were on religious holy days, and in general. Characteristic of our region was, above all, the custom of the "moba" (joint work for an interest of one family, without money compensation). Moba was called for urgent work. The main moba works are mowing, harvesting, digging, picking. 
And fruit harvesting was often done using the moba. Moths are primarily organized for crop production activities. In addition, there are mobas that do not serve for the agricultural production. These include moba for building houses and other buildings, for wood cutting, help with bricks and other materials transport. This folk tradition has an important role in women's home work, usually called "prelo" (wool spinning). Most people invited for the moba are relatives, neighbors and good friends. Mobas are most often convened in summer and autumn (which does not apply to prela) and in saints, on less important religious holidays, when peasants are not allowed to work for them because it is a sin. On the other hand, it is considered that there is no sin in work if it helps others (Vlajinac, 1929: 433).

How much is the traditional type of assistance among rural population occurs at the local level today is seen just on the case of keeping the tradition of moba (Table 8).

Table 8. The presence of "moba" - joint work

\begin{tabular}{|c|c|c|c|c|}
\hline Help & $\begin{array}{c}\text { In some agricultural } \\
\text { works }\end{array}$ & $\begin{array}{c}\text { Building houses } \\
\text { or similar }\end{array}$ & $\begin{array}{c}\text { Preparation of } \\
\text { celebration }\end{array}$ & $\begin{array}{c}\text { In doing some } \\
\text { casual jobs }\end{array}$ \\
\hline Yes & 44,5 & 29,9 & 42,0 & 50,9 \\
\hline Sometimes & 33,8 & 25,6 & 25,3 & 18,5 \\
\hline No & 20,6 & 43,4 & 31,0 & 29,9 \\
\hline No answer & 1,1 & 1,1 & 1,8 & 0,7 \\
\hline Total & 100,00 & 100,0 & 100,0 & 100,0 \\
\hline
\end{tabular}

Source: Authors' calculations

It turned out that the help that neighbors, friends, relatives provide to a householder without money compensation, is most prominent precisely when performing agricultural works, as well as assistance especially among women when preparing some important celebrations in the life of a rural family (Table 8). And mobas that do not serve agricultural production, but are organized when building houses or similar, have remained in the present time.

\section{Conclusion}

The two basic traditional values in all peasant societies are the value of the land and the value of the family. The family replaces those groups and institutions that do not exist in the village, but are present only in the urban areas, thus representing a prototype for all other social communities. In rural areas there is a family organization of economy, family housing, socialization of children, and all cultural patterns in the village bear a sign of family relations (Mitrović, 1998: 295). The family is the basic framework of social life in a village where the primary family and family/relatives connection has not been lost to the present. Nonetheless, the rural family, viewed from a historical perspective, suffered great changes. One of them is the size of the family group. Thus, the most common type of family in selected farms - family made up of parents and children, while only every third family was extended/enlarged family. A large number of children are not any more the characteristic of the rural environment. 
On the other hand, high marriage rate is still a feature of Serbian rural areas, with the difference that the age of marriage was moved to a later year of the marital contingent, but nevertheless remained below the average for Serbia. In addition to the fact that agricultural holdings are not usually registered on women, the power to decide on agricultural production has been kept in the hands of men by keeping the patriarchal pattern. Thus, women do not usually decide on agricultural production, although they are included in it. However, the house is (remained) a woman's sphere: housework, household and children care are almost entirely entitled to women. The above findings point to another conclusion: the gender division of labor persists in Serbian village, but also solidarity and support from traditional resource groups such as neighbors, relatives and friends in performing agricultural and some other works. The survival of traditional values is something that must be considered when it comes to the socialization of children with whom they are transferred to younger generations, since, among other things, they will depend on the commitment of these generations to continue cultivating agriculture and to live in the rural areas

\section{Acknowledgements}

The paper is part of the research on the project Sustainable agriculture and rural development in terms of the Republic of Serbia strategic goals' implementation within Danube region (III 46006), and project Rural labour markets and rural economy of Serbia - the diversification of income and poverty reduction (ON 179028).

\section{Conflict of interests}

The authors declare no conflict of interest.

\section{References}

1. Babović, M., Vuković, O. (2009). Women in rural areas as assisting members of the agricultural household: position, role and social rights, UNDP, Belgrade [in Serbian: Babović, M., Vuković, O. (2009). Žene na selu kao pomažući članovi poljoprivrednog domaćinstva: položaj, uloge i socijalna prava].

2. Blagojević, M. (1997). Parenthood and fertility - Serbia in the nineties. Belgrade: ISI FF. [in Serbian: Blagojević, M. (1997). Roditeljstvo i fertilitet - Srbija devedesetih].

3. Bogdanov, N.; Babović, M. (2014). Labourforce and activity of farms. Belgrade: Statistical office of the Republic of Serbia. [in Serbian: Bogdanov, N.; Babović, M. (2014) Radna snaga i aktivnosti poljoprivrednih gazdinstava].

4. Burić, O. (1963). Years of marriage and early marriages in Yugoslavia, Sociologija, Belgrade, Vol. 5/1-2. Pp. 79- 84 [in Serbian: Burić, O. (1963). Godine stupanja u brak i rani brakovi u Jugoslaviji].

5. Đorđević, T. (1930). Our National Life, Book 2, Izdavačka knjižarnica Gece Kona, Belgrade [in Serbian: Đorđević, T. (1930). Naš narodni život, knjiga 2]. 
6. Erlih, V.(1971). A Yugoslav family in transformation: study in three hundred villages. Zagreb: Liber. [in Serbian: Erlih, V.(1971). Jugoslovenska porodica u transformaciji: studija u tri stotine sela].

7. First-Dilić, R. (1973). Hipothetical frame for the research of rural family. Sociologija sela. Vol. XI, No. 2-4, Zagreb. [in Serbian: First-Dilić, R. (1973). Hipotetski okvir za istraživanje poljoprivredne porodice].

8. First-Dilić, R. (1973a). The marital division of labour in the life cycle of the agricultural family. Sociologija sela. Vol. XI, No. 2-4, Zagreb. [in Serbian: First-Dilić, R. (1973a). Bračna podjela rada u životnom ciklusu poljoprivredne porodice].

9. First, R. (1981). Rural family today - continuity or change. Zagreb: Institut za društvena istraživanja Sveučilišta u Zagrebu. [in Serbian: First-Dilić, R. (1981). Seoska porodica danas - kontinuitet ili promjene].

10. Milić, A. (1986). Rural family in change. Matica Srpska Journal of Social Science, Vol. 81. Novi Sad. [in Serbian: Milić, A.(1986). Seoska porodica u procesu menjanja].

11. Milić, A. (1989). A rural woman in formal and informal relationships Matica Srpska Journal of Social Science, Vol. 86/87. Novi Sad. [in Serbian: Milić, A. (1989). Seoska žena u svetlu formalnih i neformalnih odnosa].

12. Milić, A. (Ed.) (2004). Social transformation and strategies of social groups: Everyday life of Serbia at the beginning of the third millennium. Belgrade: ISI FF. [in Serbian: Milić, A. (Ed.) (2004). Društvena transformacija i strategije društvenih grupa: Svakodnevica Srbije na početku trećeg milenijuma].

13. Mitrović, M. (1998). Rural sociology. Serbian Sociological Society, Belgrade [in Serbian: Mitrović, M. (1998). Sociologija sela].

14. Mitrović, M. (1999). Serbian village - an annex to sociology of traditional Serbian society. Novi Sad: Matica srpska. [in Serbian: Mitrović, M. (1999). Srpsko selo - Prilog sociologiji tradicionalnog srpskog društva].

15. Novakov, M, \& Janković, D. (2016). Education as a factor of technological progress and determinant of human resources in agriculture. International scientific conference: Sustainable agriculture and rural development in terms of the Republic of Serbia strategic goals realization within the Danube regiondevelopment and application of clean technologies in agriculture, Belgrade, pp.197-215.

16. Novakov, M. (2011a). The work role of a rural woman as an actor in the development of local rural communities. Economics of agriculture, Vol. LVIII, pp. 122-129 [in Serbian: Novakov, M. (2011a). Radna uloga seoske žene kao aktera razvoja lokalnih seoskih zajednica]. 
17. Novakov, M. (2011). Family and social status of mother in rural community, Faculty of agriculture, Novi Sad [in Serbian: Novakov, M. (2011). Porodični i društveni položaj majke u selu].

18. Census of Population, Households and Housing 2011. Education level, literacy and computer literacy (2013). Statistical office of the Republic of Serbia, Belgrade [in Serbian: Popis stanovništva, domaćinstva i stanova 2011. Školska sprema, pismenost i kompjuterska pismenost (2013)].

19. Census of Population, Households and Housing 2011. Households by number of members. (2013). Statistical office of the Republic of Serbia. Belgrade [in Serbian: Popis stanovništva, domaćinstva i stanova 2011. Domaćinstva prema broju članova (2013)].

20. Census of Population, Households and Housing 2011. Families with children (2014). Statistical office of the Republic of Serbia. Belgrade [in Serbian: Popis stanovništva, domaćinstva i stanova 2011. Porodice sa decom (2014)].

21. Rašević, M.(1999). Family planning as a lifestyle. Institute of social sciences, Belgrade [in Serbian: Rašević, M.(1999). Planiranje porodice kao stil života].

22. Statistical yearbook (2015). Statistical office of the Republic of Serbia. Belgrade. [in Serbian: Statistički godišnjak (2015)].

23. Population statistics. Married and divorced marriages in the Republic of Serbia in 2015 (2016). No.169, Statistical office of the Republic of Serbia, Belgrade [in Serbian: Statistika stanovništva. Zaključeni i razvedeni brakovi u Republici Srbiji 2015 (2016)].

24. Stojanov, M.(1989). Rural women in economic development. Matica Srpska Journal of Social Science, No. 86/87, Novi Sad [in Serbian: Stojanov, M.(1989). Seoska žena u privrednom razvoju].

25. Šljukić, S.; Janković, D. (2015). The rural in the sociological mirror. Novi Sad: Mediterran publishing. [in Serbian: Šljukić, S.; Janković, D. (2015). Selo u sociološkom ogledalu].

26. Tomanović, S. (Ed.) (2006). Society in transformation - sociological studies of some aspects of social transformation in Serbia. Belgrade: ISI FF. [in Serbian: Tomanović, S. (Ed.) (2006). Društvo u previranju - Sociološke studije nekih aspekata društvene transformacije u Srbiji].

27. Tripković, G. (1997). Motherhood - cultural pattern of Serbs. Matica Srpska. Novi Sad. [in Serbian: Tripković, G. (1997). Materinstvo - kulturni obrazac Srba.].

28. Tripković M.(1987). Village and culture. Novi Sad: Književna zajednica Novog Sada. [in Serbian: Tripković, M. (1987). Selo i kultura]. 
29. Vlajinac, M. (1929). Moba and loan. National customs of associated labor - description, assessment and their present state. Serbian royal academy, Belgrade [in Serbian: Vlajinac, M. (1929). Moba i pozajmica. Narodni običaji udruženog rada - opis, ocena i njihovo sadašnje stanje].

30. Vukosavljević, S. (1962). Letters from the village. Savremena škola. Belgrade [in Serbian: Vukosavljević, S. (1962). Pisma sa sela].

31. Vukosavljević, S. (1983). The history of peasant society III. SANU, Belgrade [in Serbian: Vukosavljević, S. (1983). Istorija seljačkog društva III ].

32. Women and men in Republic of Serbia (2014). Statistical office of the Republic of Serbia, Belgrade [in Serbian: Žene i muškarci u Republici Srbiji (2014)]. 